\title{
ANALISIS TATA KELOLA TEKNOLOGI INFORMASI UNTUK MENDEFINISIKAN PROSES TI PADA STIE 45 MATARAM DENGAN MENGGUNAKAN FRAMEWORK COBIT 4.1
}

\author{
(Information Technology Governance Analysis to Define the IT Process at STIE 45 \\ Mataram Using the COBIT Framework 4.1) \\ Nabhan Rabbani, Nadiyasari Agitha*, Sri Endang Anjarwani \\ Dept of Informatics Engineering, Mataram University \\ Jl. Majapahit 62, Mataram, Lombok NTB, INDONESIA \\ Email:nabhanrabbani@gmail.com,nadiya@unram.ac.id, endang@unram.ac.id
}

\begin{abstract}
STIE 45 Mataram is in the stage of implementing information technology in achieving the existing vision and mission. But there are problems such as the absence of a special section that controls the management of information technology, the lack of staff who are skilled in the IT field and the responsibility for each IT team member who is not yet organized. Therefore, a guide is needed to help resolve this problem, which is in this study uses the COBIT 4.1 Framework. The selected IT process attributes are PO4 and AI7. The average attribute condition is currently at maturity level 2. The expected condition is at maturity level 4 except the attribute SE in PO4 which is at maturity level 5. The recommendations are given in the form of steps to increase the maturity level, form an action plan equipped with an implementation schedule and estimated time that can be run.
\end{abstract}

Keywords: IT Governance, COBIT 4.1, maturity level, recommendations, IT process.

*Penulis korespondensi

\section{Pendahuluan}

Teknologi informasi (TI) saat ini sudah menjadi kebutuhan yang sangat penting bagi hampir semua organisasi perusahaan. Dengan adanya keterbatasan sumber daya (seperti data, sistem aplikasi, teknologi, fasilitas dan sumber daya manusia) serta adanya kebutuhan informasi yang berkualitas merupakan faktor utama mengapa pemanfaatan teknologi informasi perlu direncanakan secara sistematis [1].

Framework COBIT 4.1 menyelesaikan permasalahan berdasarkan proses $\mathrm{TI}$ yang terpilih dimana terdapat proses yang dapat memberikan solusi untuk memperbaiki proses TI di STIE 45 Mataram dengan membentuk kerangka kerja proses TI-nya, membangun peran serta kesadaran akan tanggung jawab masing-masing stakeholder yang berhubungan dengan STIE 45 Mataram, membentuk manajemen resiko dan keamanan, melakukan pengawasan pada fungsi TI agar berjalan dengan benar, membuat kebijakan dan prosedur mengenai kontrak pegawai untuk mendukung dan melindungi aset informasi, serta melatih staf yang berhubungan langsung dengan perusahaan, kelompok operasional dan yang berhubungan dengan fungsi TI dengan pelatihan yang sesuai.

Saat ini STIE 45 Mataram sedang dalam tahap untuk menerapkan teknologi informasi sebagai salah satu cara untuk mencapai visi dan misi. Tetapi dalam proses pengembangannya masih ada kendala yang dihadapi. Oleh karenanya diperlukan panduan untuk membentuk kerangka kerja proses $\mathrm{TI}$, membangun bagian yang mengawasi jalannya proses TI, membentuk struktur organisasi, membangun tugas dan tanggungjawab yang diberikan kepada staf yang sesuai dengan perannya serta membangun hubungan internal dan eksternal yang berhubungan dengan proses TI STIE 45 Mataram. Atas dasar tersebut, pada kesempatan ini akan dilakukan penilaian penerapan proses tata kelola teknologi informasi yang sudah berjalan pada STIE 45 Mataram dan memberikan solusi dengan meggunakan Framework COBIT 4.1.

\section{TINJAUAN PUStaka}

\subsection{Tinjauan Pustaka}

Penelitian tata kelola teknologi informasi yang dilakukan oleh Pardiansyah di tahun 2015 pada Program Studi Sistem Informasi Sekolah Tinggi Manajemen Informatika dan Komputer (STMIK) 
Lombok dengan menggunakan Framework COBIT 4.1 didapatkan bahwa tingkat kematangan level yang dicapai rata-rata memiliki nilai 2 yaitu repeatable yang artinya Prodi SI memiliki pola untuk mengelola proses berdasarkan pengalaman yang berulang-ulang yang pernah dilakukan sebelumnya. Prodi SI telah menerapkan prosedur untuk dipatuhi oleh karyawan, namun belum ada pelatihan dan komunikasi formal dari prosedur standar kepada setiap karyawan sehingga tanggung jawab dan kepercayaan penuh diberikan kepada individu yang mana dapat memungkinkan terjadinya penyimpangan. Rekomendasi yang diberikan kepada Prodi SI adalah diperbanyaknya pelatihan dan pendidikan kepada staf Prodi SI, mengidentifikasi kebutuhan pendidikan dan pelatihan bagi staf serta mengevaluasi hasil pendidikan pelatihan bagi staf Prodi SI [2].

Pada penelitian tata kelola teknologi informasi yang dilakukan oleh Saputro di tahun 2017 pada PDAM Surabaya mendapatkan nilai as-is pada level Defined Process dan mendapat nilai to-be pada level Manage and Measurable. Terdapat kesenjangan atau gap sebesar 0.89 dari hasil gap analysis yang akan di proses sebelum beranjak naik ke tingkat kematangan yang diharapkan. Terdapat 22 rekomendasi penerapan tata kelola teknologi informasi berdasarkan framework COBIT 4.1 yang mencangkup 4 domain utama COBIT 4.1. Rekomendasi tersebut meliputi IT strategic planning sebagai standar praktis, Teknik pengembangan information architecture, respon perubahan proaktif, mengkomunikasikan kebijakan, tanggung jawab IT Resources didelegasikan, pembahasan QMS, matrik proyek, IT Solution Method, serta pelaporan hasil monitoring [3].

Pada penelitian lainnya yang dilakukan oleh Hamka dan Wibowo di tahun 2015 pada UMKM Etsa Luhur mendapatkan hasil analisis pengukuran tingkat kematangan terkait strategi pengembangan TI berada pada level 0. Artinya UMKM Etsa Luhur belum memiliki kepedulian untuk pengelolaan TI secara baik. Arah pengembangan TIK di UMKM Etsa Luhur ditargetkan mencapai level 3. Dengan begitu langkah-langkah yang direkomendasikan yaitu perlu dilakukan penyusunan dokumentasi kebutuhan, arah, standarisasi dan strategi pengembangan TI. Selain itu juga diperlukan divisi TI yang bertugas mengimplementasikan kebijakan pengembangan $\mathrm{TI}$ [4].

Dari hasil 3 penelitian di atas dapat disimpulkan bahwa peran dan tanggung jawab dari masing-masing orang yang terlibat di dalam tata kelola teknologi informasi pada suatu instansi mempengaruhi jalannya proses tata kelola teknologi informasinya. Peran dan tanggung jawab serta kebijakan-kebijakan yang berlaku sangat diperlukan, agar dalam prosesnya dapat sejalan dengan visi dan misi instansi. Adapun hal-hal yang dapat dilakukan untuk membuat proses tata kelola teknologi informasi berjalan sesuai dengan visi, misi dan tujuan instansi yaitu dengan melatih dan mendidik staf-staf $\mathrm{Tl}$, mendefinisikan dan mensosialisasikan kebijakan, prosedur serta standar yang dibutuhkan dalam pengelolaan informasi. Begitupun juga dengan penelitian yang dilakukan di STIE 45 Mataram memiliki permasalahan yang tidak jauh berbeda, yaitu terdapat masalah pada penerapan tugas, peran, kebijakan serta tanggungjawab masingmasing stakeholder. Sesuai dengan proses TI yang terpilih akan diberikan gambaran tentang penerapan tugas, peran, kebijakan serta tanggungjawab untuk setiap stakeholder dan rekomendasi untuk menunjang kwalitas stakeholder. Tentunya hal itu akan dilakukan secara bertahap dimulai dengan mencari tingkat kematangnnya agar diketahui sejauh mana penerapan tata kelola teknologi informasi yang sudah berjalan dengan menggunakan Framework COBIT 4.1. Sehingga nantinya dapat diberikan rekomendasi perbaikan sesuai dengan tingkat kematangan dan kondisi tata kelola teknologi informasi yang ada saat ini maupun kondisi yang diinginkan.

\subsection{Dasar Teori}

\subsubsection{Tata Kelola Teknologi Informasi}

Tata kelola teknologi informasi merupakan tanggung jawab dari pimpinan tertinggi dan eksekutif manajemen dari suatu perusahaan. IT Governance merupakan bagian dari pengelolaan perusahaan secara keseluruhan yang terdiri dari kepemimpinan, struktur organisasi, proses yang ada untuk memastikan kelanjutan organisasi $\mathrm{TI}$, pengembangan strategi dan tujuan dari organisasi [5].

\subsubsection{COBIT}

COBIT adalah sekumpulan dokumentasi best practices untuk IT Governance yang dapat membantu auditor, pengguna dan manajemen untuk menjembatani pembatas antara risiko bisnis, kebutuhan kontrol dan masalah-masalah teknis TI, serta Best Business Practices yang mencakup keseluruhan $\mathrm{TI}$ dan kaitannya dengan proses bisnis perusahaan untuk memaparkannya dalam struktur aktivitas-aktivitas logis yang dapat dikelola serta dikendalikan secara efektif.

\subsubsection{Komponen Control Objectives}
a. Plan and Organise
(Perencanaan
dan Organisasi) 
Mencakup strategi, taktik dan identifikasi konstribusi terbaik TI demi pencapaian tujuan perusahaan. Pada tahap plan and organise dibagi atas 10 bagian yang mendukung terwujudnya perencanaan dan organisasi yang baik. Bagian-bagian tersebut yaitu:

1. PO1 Define a strategic IT Plan (mendefinisikan rencana $\mathrm{Tl}$ strategis)

2. PO2 Define the Information Architecture (mendefinisikan arsitektur teknologi informasi)

3. $\mathrm{PO} 3$ Determine technological direction (menentukan arah teknologi)

4. PO4 Define the IT Procceses, organisation and relationships (mendefinisikan organisasi TI dan hubungannya)

5. PO5 Manage the IT Investment (mengelola investasi $\mathrm{TI}$ )

6. PO6 Communicate management aims and direction (mengkomunikasikan tujuan dan arah manajemen)

7. PO7 Manage the IT human resources (mengelola SDM)

8. PO8 Manage Quality (mengelola kualitas)

9. PO9 Assess and manage IT Risk (Menilai dan Mengelola Risiko TI)

10. P010 Manage Projects (mengelola proyek)

b. Acquire and Implement (Pengadaan dan Implementasi)

Untuk merealisasikan strategi TI, perlu dilakukan pengidentifikasian, pengembangan dan perolehan solusi TI, sesuai dengan yang akan diimplementasikan dan diintegrasikan ke dalam proses bisnis. Pada tahap Acquire and Implement (akuisisi dan implementasi) dibagi atas tujuh bagian, yaitu:

1. Al1 Identify automated solutions (identifikasi solusi otomatis)

2. Al2 Acquire and maintain application software (memperoleh dan memelihara software aplikasi)

3. Al3 Acquire and maintain technology infrastructure (memperoleh dan memelihara infrastruktur teknologi)

4. Al4 Enable operation and use (Memungkinkan operasi dan penggunaan)

5. Al5 Procure IT resources (Mendapatkan sumber daya $\mathrm{TI}$ )

6. Al6 Manage Changes (mengelola perubahan)
7. Al7 Install and accredit solutions and changes (menginstal dan mengakreditasi sistem dan perubahannya)

c. Deliver and Support (Pengiriman Layanan dan Dukungan)

Domain ini fokus terhadap penyampaian jasa yang sesungguhnya diperlukan, termasuk penyediaan layanan, manajemen keamanan dan kontinuitasnya, jasa dukungan kepada user dan manajemen data dan fasilitas operasi. Pada tahap Deliver and Support (pengiriman layanan dan dukungan) terdiri atas 13 bagian, yaitu:

1. DS1 Define and manage service levels (menentukan dan mengelola tingkat layanan)

2. DS2 Manage third-party services (mengelola layanan pihak ketiga)

3. DS3 Manage performance and capacity (mengelola kinerja dan kapasitas)

4. DS4 Ensure Continous System (menyakinkan keberlanjutan sistem)

5. DS5 Ensure system security (memastikan keamanan sistem)

6. DS6 Identify and allocate costs (identifikasi dan alokasi biaya)

7. DS7 Educate and train users (mendidik dan melatih pengguna)

8. DS8 Manage service desk and incidents (mengolala meja layanan dan insideninsiden)

9. DS9 Manage the configuration (mengelola konfigurasi)

10.DS10 Manage problems (mengelola masalah)

11. DS11 Manage data (mengelola data)

12.DS12 Manage the phisycal enviroment (mengelola lingkungan fisik)

13.DS13 Manage operations (mengelola operasi)

d. Monitor and Evaluate (Pengawasan dan Evaluasi)

Berkenaan dengan manajemen kinerja, pemantauan internal control, kepatuhan terhadap regulasi dan pelaksanaan tata kelola. Pada tahap Monitor and Evaluate (pengawasan dan evaluasi) terdiri atas empat bagian, yaitu:

1. ME1 Monitor and evaluate IT performance (mengawasi dan mengevaluasi kinerja TI)

2. ME2 Monitor and evaluate internal control (mengawasi dan mengevaluasi kontrol internal) 
3. ME3 Ensure compliance with external requirments (memastikan kepatuhan dengan kebutuhan external).

4. ME4 Provide IT governance (menyediakan tata kelola teknologi informasi).

\subsubsection{Balanced Scorecard}

Balanced Scorecard merupakan sekumpulan tolak ukur kinerja yang terintegrasi yang berasal dari strategi perusahaan dan mendukung strategi perusahaan diseluruh organisasi. Tujuan dan ukuran Scorecard diturunkan dari visi, misi dan strategi. Tujuan dan ukuran memandang kinerja perusahaan dari empat perspektif: keuangan, pelanggan, proses bisnis internal, serta pembelajaran dan pertumbuhan [6].

\subsubsection{Elemen IT Resource}

Elemen-elemen sumber daya TI merupakan hal yang sangat penting di dalam pencapaian tujuan bisnis. Karena itu dibutuhkan dukungan sumber daya informasi yang memadai. Fokus terhadap pengelolaan sumber daya teknologi informasi dalam COBIT 4.1 aplikasi, informasi, infrastruktur dan manusia.

\subsubsection{Maturity Models}

Merupakan alat bantu yang dapat digunakan untuk memetakan status maturity proses. Nilai maturity level didapat dengan mencari rata-rata jawaban pada masing-masing atribut, selanjutnya akan dilakukan pembobotan terhadap hasil rata-rata tersebut.

\subsubsection{RACI Chart}

Responsible, accountable, consulted, informed (RACl) chart adalah matriks yang menggambarkan peran berbagai pihak dalam penyelesaian suatu pekerjaan dalam suatu proyek atau proses bisnis. Matriks ini sangat bermanfaat dalam menjelaskan peran dan tanggung jawab antar bagian didalam suatu proyek atau proses.

\subsubsection{Inter Quartile Range (IQR)}

Metode IQR merupakan salah satu metode yang digunakan dalam analisis statistik untuk membantu menarik kesimpulan mengenai sekumpulan data semisal data kuesioner. Pada setiap pertanyaan, jawaban dari semua responden diurutkan kemudian dicari nilai kuartil 1 (Q1) dan kuartil 3 (Q3).

\subsubsection{Uji Realibilitas dan Validitas}

Uji realibilitas ditentukan dengan menggunakan metode koefisien Cronbach's Alpha. Pengujian ini menentukan konsistensi jawaban responden atas suatu data dari sebuah penelitian. Data yang dianalisa dapat dikatakan reliabel jika memiliki koefisien Cronbach's Alpha di atas 0,60.

Uji validitas digunakan untuk mengukur valid atau tidaknya suatu kuesioner dalam sebuah penelitian. Uji validitas dalam penelitian ini menggunakan metode korelasi Pearson yang merupakan alat uji statistik yang digunakan untuk menguji hubungan antara dua variabel bila datanya berskala interval atau rasio.

\section{Metode Penelttian}

Flowchart atau diagram alir dari tahapan penelitian ini dapat dilihat pada Gambar 1.

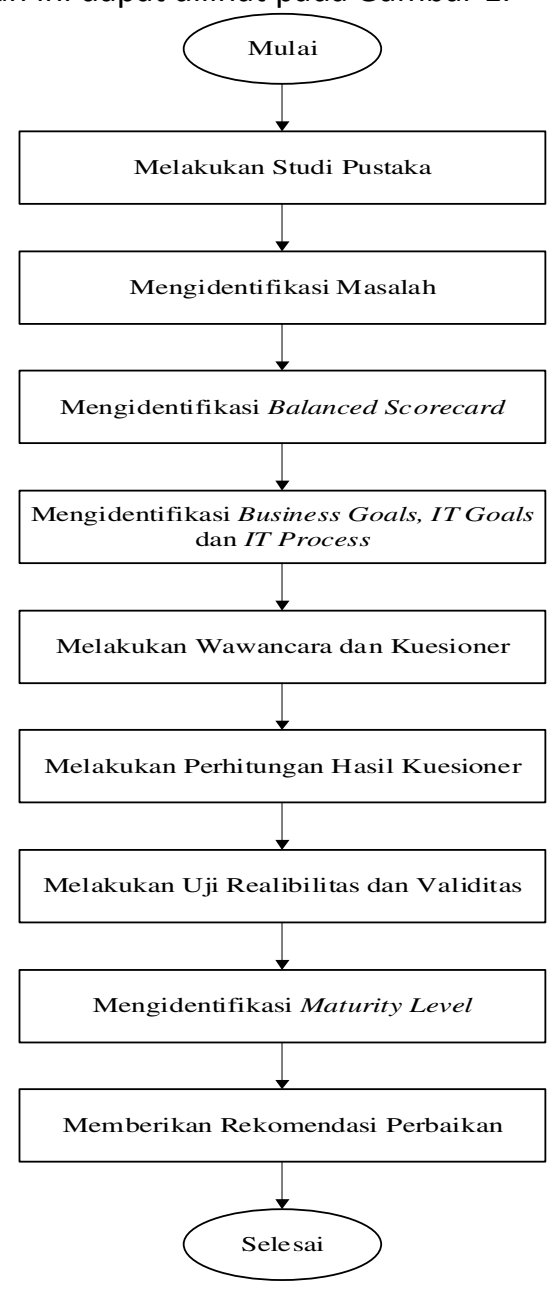

Gambar 1. Flowchart tahapan penelitian

\subsection{Melakukan Studi Pustaka}

Melakukan studi pustaka berguna untuk mencari dan mengumpulkan data yang berguna bagi penelitian.

\subsection{Mengidentifikasi Masalah}

Dilakukan pengumpulan data dengan beberapa metode seperti observasi dan wawancara kepada stakeholder yang terkait dengan tata kelola teknologi informasi pada instansi. 


\subsection{Mengidentifikasi Balanced Scorecard}

Pada tahap ini, diperlukan identifikasi terhadap visi, misi dan strategi STIE 45 Mataram. Perumusan visi dan misi ini betujuan untuk mengidentifikasi kebutuhan dan faktor-faktor yang mendukung tata kelola teknologi informasi STIE 45 Mataram. Dalam pemetaan visi dan misi STIE 45 Mataram akan dikelompokan ke dalam empat perspektif yaitu: financial perspective, customer perspective, internal Business perspective, learning and growth perspective.

\subsection{Mengidentifikasi BSC, Business Goals, IT Goals, IT Process}

Pada tahap ini, akan mengidentifikasi Business Goals, IT Goals dan IT Process. Pada Business Goals akan didefinisikan Business Goals sesuai dengan COBIT 4.1 yang diselaraskan dengan tujuan bisnis dan sasaran STIE 45 Mataram. Dalam COBIT 4.1, setiap Business Goals sudah dipetakan sesuai dengan 4 perspektif di dalam Balanced Scorecard.

Pada IT Goals dilakukan mapping untuk menentukan IT Goals yang disesuaikan dari Business Goals yang telah didefinisikan. Kemudian didapatkan keterkaitan antara Business Goals dengan IT Goals.

Pada IT Process dilakukan mapping untuk menentukan IT process yang disesuaikan dari IT Goals. Kemudian dihasilkan IT process yang berkaitan antara IT Goals dengan IT process berdasarkan Framework COBIT 4.1 yang sesuai dengan kebutuhan perusahaan. IT process yang terpilih merupakan IT process yang telah terdefinisikan sesuai dengan COBIT 4.1.

Setelah dilakukan pemetaan kebutuhan proses $\mathrm{TI}$ yang dimiliki oleh STIE 45 Mataram sesuai dengan kebutuhannya yang merupakan penjabaran dari visi dan misi. Proses TI yang akan digunakan adalah PO 4 dan Al 7 yang merupakan proses TI yang paling sering terpetakan (tetulis berulang-ulang) dan muncul dalam satu baris, sehingga dalam penelitian ini proses $\mathrm{TI}$ tersebut dapat dijadikan fokus untuk dilakukannya pengembangan dalam mencapai visi dan misi STIE 45 Mataram.

\subsection{Melakukan Wawancara dan Kuesioner}

Dalam melakukan wawancara, tentunya memiliki batasan pada permasalahan yang ingin dipecahkan. Untuk membantu dan mempermudah dalam membuat sebuah pertanyaan wawancara dengan menggunakan Framework COBIT akan disedakan control objective sebagai patokannya.

\subsection{Mengidentifikasi Maturity Level}

Dalam mengidentifikasi maturity level akan dilakukan dengan perhitungan nilai kematangan dari kondisi saat ini dan kondisi yang diharapkan. Hal ini dilakukan agar dalam penelitian ini dapat diketahui sejauh mana tingkatan dari suatu perusahaan dalam proses tata kelola teknologi informasinya.

\subsection{Memberikan Rekomendasi Perbaikan}

Untuk merekomendasikan perbaikan pada STIE 45 Mataram dilakukan dengan menggunakan proses $\mathrm{TI}$ yang terpilih dan mengacu pada Spider chart untuk meningkatkan maturity level dengan memperhatikan tingkat kematangannya, sehingga rekomendasi akan disesuaikan dengan maturity level tersebut. Dengan begitu diharapkan terciptanya struktur organisasi TI yang sesuai untuk STIE 45 Mataram, sehingga masingmasing stakeholder memiliki tanggung jawab dan perannya masing-masing untuk semua proses $\mathrm{TI}$ dan hubungannya dengan stakeholder lain yang berada di luar struktur organisasi STIE 45 Mataram.

\section{HASIL DAN PEMBAHASAN}

\subsection{Hasil Kuesioner Proses IT Terpilih}

Setelah melakukan proses wawancara dan kuesioner maka selanjutnya akan direkap jawaban dari responden ke dalam tabel rekapitulasi yang dibagi menjadi 2 yaitu data pada keadaan saat ini dan keadaan yang diinginkan.

\subsubsection{InterQuartile Range (IQR)}

Berdasarkan hasil rekapitulasi kuesioner yang telah dilakukan maka tahap selanjutnya ada menghitung nilai IQR yang akan direpresentasikan dalam bentuk Boxplot yang dapat dilihat pada Gambar 2 dan Gambar 3:

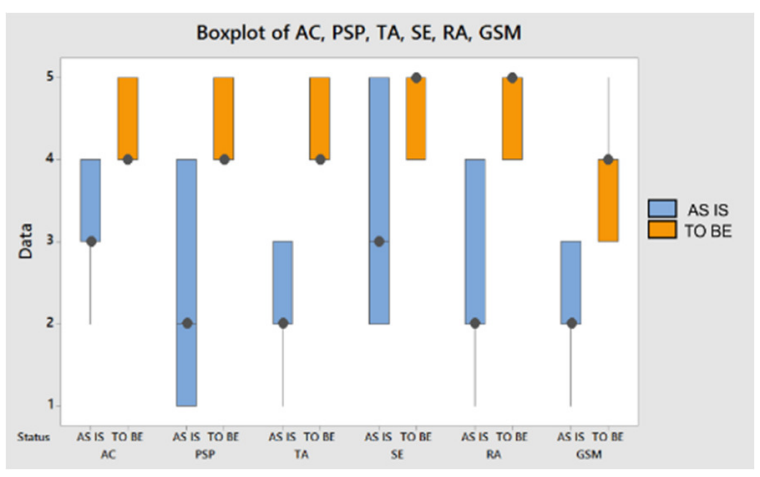

Gambar 2. Boxplot Proses TI PO4 


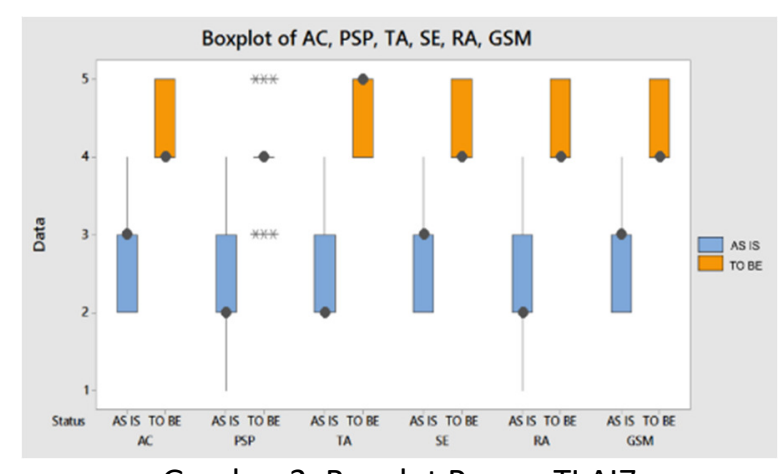

Gambar 3. Boxplot Proses TI Al7

Dari diagram Boxplot tersebut dapat dilihat bahwa simbol kotak mempresentasikan Inter Quartile Range (IQR), yaitu dengan batas bawah kotak merupakan Quartile 1 dan batas atas kotak merupakan Quartile 3. Simbol lingkaran menandakan data median atau nilai tengah dari data yang ada. Sedangkan simbol garis menunjukan batas minimal ataupun maximal dari data tersebut. Pada diagram Boxplot proses IT AI7 terlihat bahwa atribut PSP pada kondisi yang diinginkan (to-be) terdapat nilai outlier. Nilai outlier merupakan nilai yang terletak 1.5 lebih besar dari nilai IQR.

\subsubsection{Uji Reliabilitas}

Berikut dapat dilihat pada Tabel I hasil perhitungan uji reliabilitas dengan metode Cronbach's Alpha dari kedua IT Process yakni Proses PO4 dan Proses AI7.

TABEL I. HASIL UJI RELIABILITAS

\begin{tabular}{|c|c|c|c|}
\hline Proses TI & Status & Nilai & Reliabilitas \\
\hline \multirow{2}{*}{ PO4 } & $A s$ Is & 0.938 & Reliabel \\
\cline { 2 - 4 } & To Be & 0.825 & Reliabel \\
\hline \multirow{2}{*}{ Al7 } & As Is & 0.87 & Reliabel \\
\cline { 2 - 4 } & To Be & 0.79 & Reliabel \\
\hline
\end{tabular}

\subsubsection{Uji Validitas}

Berikut dapat dilihat pada Tabel II dan Tabel III hasil perhitungan uji validitas menggunakan metode Korelasi Pearson dari IT Proses PO4 dan AI7.

TABEL II. HASIL UJI VALIDITAS PO4

\begin{tabular}{|c|c|c|c|c|}
\hline Atribut & Status & r-hitung & r-tabel(N=15) & Validitas \\
\hline \multirow{2}{*}{ AC } & As is & 0.983 & 0.514 & Valid \\
\cline { 2 - 5 } & To be & 0.631 & 0.514 & Valid \\
\hline \multirow{2}{*}{ PSP } & As is & 0.935 & 0.514 & Valid \\
\cline { 2 - 5 } & To be & 0.786 & 0.514 & Valid \\
\hline \multirow{2}{*}{ TA } & As is & 0.888 & 0.514 & Valid \\
\cline { 2 - 5 } & To be & 0.763 & 0.514 & Valid \\
\hline \multirow{2}{*}{ SE } & As is & 0.943 & 0.514 & Valid \\
\cline { 2 - 5 } & To be & 0.848 & 0.514 & Valid \\
\hline \multirow{2}{*}{ RA } & As is & 0.953 & 0.514 & Valid \\
\cline { 2 - 5 } & To be & 0.649 & 0.514 & Valid \\
\hline
\end{tabular}

\begin{tabular}{|c|c|c|c|c|}
\hline Atribut & Status & r-hitung & r-tabel(N=15) & Validitas \\
\hline \multirow{2}{*}{ GSM } & As is & 0.805 & 0.514 & Valid \\
\cline { 2 - 5 } & To be & 0.764 & 0.514 & Valid \\
\hline
\end{tabular}

TABEL III. HASIL UJI VALIDITAS AI7

\begin{tabular}{|c|c|c|c|c|}
\hline Atribut & Status & r-hitung & r-tabel(N=19) & Validitas \\
\hline \multirow{2}{*}{ AC } & As is & 0.906 & 0.456 & Valid \\
\cline { 2 - 5 } & To Be & 0.730 & 0.456 & Valid \\
\hline \multirow{2}{*}{ PSP } & As is & 0.895 & 0.456 & Valid \\
\cline { 2 - 5 } & To Be & 0.959 & 0.456 & Valid \\
\hline \multirow{2}{*}{ TA } & As is & 0.687 & 0.456 & Valid \\
\cline { 2 - 5 } & To Be & 0.584 & 0.456 & Valid \\
\hline \multirow{2}{*}{ SE } & As is & 0.524 & 0.456 & Valid \\
\cline { 2 - 5 } & To Be & 0.532 & 0.456 & Valid \\
\hline \multirow{2}{*}{ RA } & As is & 0.883 & 0.456 & Valid \\
\cline { 2 - 5 } & To Be & 0.666 & 0.456 & Valid \\
\hline \multirow{2}{*}{ GSM } & As is & 0.749 & 0.456 & Valid \\
\cline { 2 - 5 } & To Be & 0.731 & 0.456 & Valid \\
\hline
\end{tabular}

\subsubsection{Mengidentifikasi Maturity Level}

Dari rekapitulasi jawaban responden yang ada, dapat dihitung maturity level STIE 45 Mataram dan dimasukan ke dalam Tabel IV untuk Maturity Level proses IT PO4 dan Tabel V Maturity Level proses IT AI7 seperti berikut:

TABEL IV. MATURITY LEVEL PO4

\begin{tabular}{|c|c|c|c|c|c|}
\hline \multirow{2}{*}{ No } & \multirow{2}{*}{ Atribut } & \multicolumn{2}{|c|}{ Kondisi As Is } & \multicolumn{2}{c|}{ Kondisi To Be } \\
\cline { 3 - 6 } & & $\begin{array}{c}\text { Nilai } \\
\text { Maturity }\end{array}$ & $\begin{array}{c}\text { Maturity } \\
\text { level }\end{array}$ & $\begin{array}{c}\text { Nilai } \\
\text { Maturity }\end{array}$ & $\begin{array}{c}\text { Maturity } \\
\text { level }\end{array}$ \\
\hline 1 & AC & 3.23 & 3.1 & 3 & 4.27 \\
\hline 2 & PSP & 3.69 & 2.3 & 2 & 4.33 \\
\hline 3 & TA & 3.69 & 2.2 & 2 & 4.27 \\
\hline 4 & SE & 3.38 & 3.2 & 3 & 4.6 \\
\hline 5 & RA & 3.38 & 2.6 & 2 & 4.53 \\
\hline 6 & GSM & 3.46 & 2.4 & 2 & 3.86 \\
\hline
\end{tabular}

TABEL V. MATURITY LEVEL AI7

\begin{tabular}{|c|c|c|c|c|c|}
\hline \multirow{2}{*}{ No } & \multirow{2}{*}{ Atribut } & \multicolumn{2}{|c|}{ Kondisi As Is } & \multicolumn{2}{c|}{ Kondisi To Be } \\
\cline { 3 - 6 } & & $\begin{array}{c}\text { Nilai } \\
\text { Maturity }\end{array}$ & $\begin{array}{c}\text { Maturity } \\
\text { level }\end{array}$ & $\begin{array}{c}\text { Nilai } \\
\text { Maturity }\end{array}$ & $\begin{array}{c}\text { Maturity } \\
\text { level }\end{array}$ \\
\hline 1 & AC & 2.8 & 2 & 4.2 & 4 \\
\hline 2 & PSP & 2.3 & 2 & 4 & 4 \\
\hline 3 & TA & 2.5 & 2 & 4.5 & 4 \\
\hline 4 & SE & 2.7 & 2 & 4.4 & 4 \\
\hline 5 & RA & 2.2 & 2 & 4.3 & 4 \\
\hline 6 & GSM & 2.7 & 2 & 4.2 & 4 \\
\hline
\end{tabular}

Untuk merepresentasikan nilai dari maturity level tiap-tiap atribut maka dibuatlah dalam bentuk grafik. Berikut adalah Spider Chart kedua proses TI PO4 dan Al7 secara berturut-turut yakni pada Gambar 3 dan Gambar 4. 


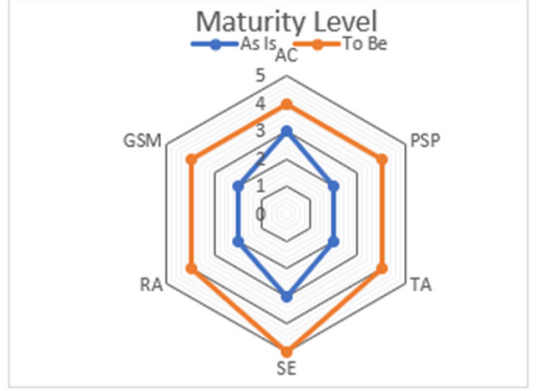

Gambar 3 Spider Chart Proses TI PO4

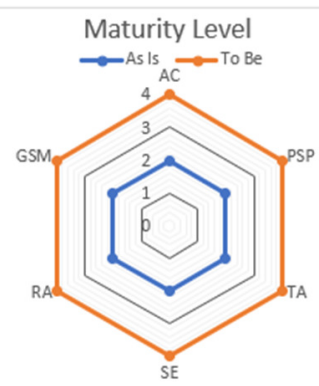

Gambar 4 Spider Chart Proses TI Al7

Dari Gambar 3 dan 4 dapat dilihat tingkat kematangan pada keadaan sekarang dan keadaan yang diinginkan untuk setiap atributnya.

\subsection{Analisa Kondisi Proses IT}

\subsubsection{Analisa Kondisi Saat Ini pada Proses IT PO4}

Atribut AC berada pada level 3 yang berarti STIE 45 Mataram memiliki kepedulian tehadap sumber daya manusia yang menjalankan proses IT. Komunikasi yang dilakukan sudah sejalan dengan strategi yang dimiliki.

Atribut PSP berada pada level 2 yang berarti STIE 45 Mataram telah menyadari bahwa kebijakan, standar dan prosedur itu penting. STIE 45 Mataram telah menjalankan beberapa kebijakan yang telah ditentukan.

Atribut TA berada pada level 2 yang berarti bahwa STIE 45 Mataram telah memiliki perangkat yang dapat menunjang proses IT yang dijalankan. Perangkat yang ada tidak digunakan secara maksimal.

Atribut SE berada pada level 3 yang berarti bahwa STIE 45 Mataram sudah memiliki beberapa staf yang dapat menjalankan proses IT. Keahlian dan ketrampilan yang dimiliki bagian IT bisa dikatakan sesuai dengan tanggungjawab yang telah diberikan. Keahlian yang dimiliki belum merata untuk semua staf IT yang berjumlah 4 orang.

Atribut RA berada pada level 2 yang berarti bahwa STIE 45 Mataram sudah menyadari pentingnya menjaga tanggung jawab dalam menjalankan proses IT. Belum adanya fungsi kontrol yang konsisten untuk mengawasi kinerja dan tanggung jawab masing-masing staf. Selama ini fungsi pengawasan hanya dilakukan pihak Yayasan ataupun Ketua STIE 45 Mataram.

Atribut GSM berada pada level 2 yang berarti bahwa STIE 45 Mataram memiliki pengawasan terhadap proses IT yang berjalan agar sesuai dengan tujuan yang ingin dicapai. Belum ada koordinasi yang dilakukan dalam proses pengawasannya.

\subsubsection{Analisa Kondisi yang Diinginkan pada Proses IT PO4}

Atribut AC berada pada level 4 yang berarti bahwa tingkat kesadaran dan kepedulian yang dimiliki STIE 45 Mataram proaktif dalam menangani berbagai situasi dan kondisi yang terjadi. Perlu adanya pembentukan komite strategi IT, yaitu badan atau tim yang terbentuk dari berbagai bagian yang tugasnya membantu Ketua dalam mengambil keputusan dan memastikan jalannya proses IT sesuai dengan strategi IT. Komunikasikan halhal yang dianggap penting ke seluruh kepala bagian juga menjadi peran komite strategi IT tersebut.

Atribut PSP berada pada level 4 yang berarti bahwa STIE 45 Mataram menginginkan kebijakan, standar dan prosedur yang dibuat untuk menjalankan proses IT dapat dikelola dan terorganisir dengan baik. Setiap kebijakan, standar dan prosedur yang ada dibuat terintegrasi dengan sistem informasi yang dapat memberikan atau menyediakan informasi yang akurat dari semua bagian. Dibuatnya kebijakan dan prosedur mengenai kontrak pada pegawai yang disepakati dan diatur secara jelas, dapat melindungi aset informasi organisasi.

Atribut TA berada pada level 4 yang berarti bahwa STIE 45 Mataram memiliki rencana untuk menyediakan perangkat yang dapat membantu staf IT dalam merespon perubahan secara cepat dan dapat memenuhi kebutuhan. Penggunakan perangkat IT yang tersedia juga diharapkan dapat memantau perkembangan organisasi serta meningkatkan kualiatas hubungan kerja sama yang ada.

Atribut SE berada pada level 5 yang berarti bahwa STIE 45 Mataram menginginkan tingkat keahlian yang dimiliki staf, khusunya pada bagian IT secara teknis dapat diandalkan dan struktur organisasinya berjalan dengan baik. Akan dibentuk bagian yang memantau jalannya proses IT, sehingga teknologi yang dimanfaatkan sejalan dengan keahlian yang dimiliki staf IT untuk mendukung kompleksitas dan tujuan organisasi.

Atribut RA berada pada level 4 yang berarti bahwa proses kepemilikan, akuntabilitas dan tanggung jawab telah didefinisikan dengan seimbang, sehingga dalam praktiknya staf IT menjalankan peran dan tanggung 
jawab sesuai dengan fungsi IT yang ditetapkan. Terdapat komite strategi yang jelas mengontrol peran dan tanggung jawab staf IT.

Atribut GSM berada pada level 4 yang berarti bahwa fungsi pengawasan untuk memantau jalannya proses IT telah diterapkan secara terorganisasi dan proaktif. Tujuan yang dimiliki telah distandarisasi. Struktur organisasi IT secara tepat mencerminkan kebutuhan STIE 45 Mataram dengan menyediakan layanan yang sesuai dengan strategi IT.

\subsubsection{Analisa Kondisi Saat Ini pada Proses IT Al7}

Atribut AC berada pada level 2 yang berarti bahwa STIE 45 Mataram memiliki kepedulian tehadap perubahan kebutuhan dan menyadari bahwa resiko apapun dapat terjadi sewaktu-waktu. Pengujian terhadap sistem baru seperti SIAKAD sudah berjalan di lingkungan STIE 45 Mataram tetapi praktik dan pelatihan belum dilakukan secara konsisten.

Atribut PSP berada pada level 2 yang berarti bahwa STIE 45 Mataram telah menyadari bahwa kebijakan, standar dan prosedur itu penting. Bagian IT diberikan wewenang untuk mengambil keputusan jika sewaktuwaktu terjadi resiko gangguan pada sistem. Belum adanya SOP yang pasti untuk mengatur bagian IT dalam mengambil tindakan.

Atribut TA berada pada level 2 yang berarti bahwa STIE 45 Mataram telah menyadari perangkat yang ada harus dapat merespon perubahan kebutuhan yang terjadi. Penggunaan perangkat teknologi untuk menunjang aktivitas STIE 45 Mataram seperti proses kerja sama yang dilakukan dengan perguruan tinggi lain dan proses belajar mengajar sudah dilakukan.

Atribut SE berada pada level 2 yang berarti bahwa STIE 45 Mataram pada tahap ini telah menyadari pentingnya memiliki keahlian dalam menanggapi perubahan kebutuhan ataupun resiko-resiko yang dapat terjadi. Belum adanya pelatihan formal bagi staf IT secara merata. Pelatihan hanya dilakukan oleh pusat yaitu RISTEKDIKTI dan diikuti oleh staf yang dipilih saja.

Atribut RA berada pada level 2 yang berarti bahwa STIE 45 Mataram sudah menyadari bahwa tanggung jawab dalam menanggapi perubahan itu penting. Pemilik proses dan data telah didefinisikan. Bagian IT mengontrol jalannya proses IT, menjaga keamanan sistem dan data STIE 45 Mataram.

Atribut GSM berada pada level 2 yang berarti bahwa STIE 45 Mataram sudah menyadari bahwa pengawasan itu penting dilakukan. Pengawasan yang dilakukan belum konsisten dan terjadwal, baik oleh Ketua STIE 45 Mataram maupun pihak Yayasan. Sudah terdapat pelaporan secara berkala mengenai pengujian terhadap sistem yang sedang dikembangkan.

\subsubsection{Analisa Kondisi yang Diinginkan pada Proses IT Al7}

Atribut AC berada pada level 4 yang berarti bahwa tingkat kesadaran dan kepedulian yang dimiliki STIE 45 Mataram dalam menanggapi perubahan teknologi telah dikelola dan sudah terencana. Hasil pengujian sistem baru selanjutnya akan melalui proses evaluasi dan diperbaiki jika terdapat kesalahan yang teridentifikasi.

Atribut PSP berada pada level 4 yang berarti bahwa STIE 45 Mataram menginginkan kebijakan, standar dan prosedur yang dibuat sudah terorganisir dengan baik sesuai kondisi STIE 45 Mataram dan telah diakreditasi. Perlunya pembuatan prosedur yang disesuaikan dengan perubahan teknologi dan disepakati untuk digunakan bersama. Seluruh bagian yang ada menjalankan kebijakan, standar dan prosedur yang telah disepakati.

Atribut TA berada pada level 4 yang berarti bahwa STIE 45 Mataram berencana untuk mengelola perangkat yang dimiliki agar dapat mengikuti perubahan dengan tetap meng-update perangkat yang digunakan secara berkala. Pelaporan akan kebutuhan perangkat tetap dilakukan dan mengacu pada hasil pengujian lingkungan yang dilakukan.

Atribut SE berada pada level 4 yang berarti bahwa STIE 45 Mataram menginginkan staf IT memiliki keahlian yang dapat mengikuti perubahan kebutuhan teknologi yang terjadi. Pelatihan teknologi dilakukan disetiap bagian yang menggunakan operasi dari fungsi IT. Staf ahli menjadi bagian penting dalam memberikan arahan mengenai teknologi yang digunakan. Seperti melakukan sosialisasi dan pelatihan secara berkala untuk staf dan dosen dalam menggunakan sistem baru.

Atribut RA berada pada level 4 yang berarti bahwa tingkat tanggung jawab yang dimiliki dalam merespon perubahan cukup cepat. Praktik yang dilakukan bagian IT dapat mengatasi perubahan yang terjadi hingga dapat memuaskan STIE 45 Mataram, walaupun evaluasi yang dilakukan masih kurang. Rencana uji akan terus dilakukan sesuai kebutuhan STIE 45 Mataram dan implementasi sistem akan dilakukan secara berkala setelah mendapatkan persetujuan.

Atribut GSM berada pada level 4 yang berarti bahwa tingkat pengawasan yang diberikan pihak STIE 45 Mataram untuk perkembangan teknologi disesuaikan dengan tujuan yang dimiliki. Solusi untuk menanggapi perubahan telah dianalisis dan digunakan untuk perbaikan proses secara berkelanjutan. Dalam menanggapi perubahan teknologi yang terjadi, bagian 
IT harus dapat membuat rencana yang tersetruktur, rencana uji coba secara bertahap dan rencana implementasi secara berkala.

\subsection{Analisis Gap}

Menaikan tingkat kematangan seluruh atribut yang berada pada nilai kematangan 2 menjadi 3 merupakan cara untuk mendapatkan keseragaman tingkat kematangan tersebut. Setelah semua atribut mencapai tingkat kematangan 3, proses selanjutnya yaitu dengan menaikan tingkat kematangan seluruh atribut menjadi 4.

\subsection{Rekomendasi Perbaikan}

Seperti yang dijelaskan sebelumnya, rekomendasi tindakan perbaikan dibagi menjadi 3 bagian agar proses peningkatan kematangan dapat berjalan dengan efektif. Untuk merekomendasikan perbaikan pada STIE 45 Mataram dilakukan dengan menggunakan proses $\mathrm{Tl}$ yang terpilih dan mengacu pada spider chart untuk meningkatkan maturity level dengan memperhatikan tingkat kematangannya, sehingga rekomendasi akan disesuaikan dengan maturity level tersebut. Dari tahapan tersebut, akan direkomendasikan perbaikan proses $\mathrm{TI}$ yang memungkinkan untuk menjalanan tata kelola teknologi informasi yang sesuai dengan Framework COBIT.

\subsubsection{Pencapaian Maturity Level 3}

Tindakan yang perlu dilakukan agar nilai kematangan pada tingkat kematangan 2 mencapai tingkat kematangan 3 pada proses IT PO4, yaitu:

a. Pada atribut PSP, melakukan penyelarasan tindakan dengan strategi IT dan menentukan kebijakan mengenai kontrak pegawai.

b. Pada atribut TA, menggunakan perangkat standar untuk mengembanngkan proses, organisasi IT untuk menglola hubungan dengan pihak-pihak terkait dan membuat dokumentasi penggunaan perangkat teknologi secara berkala.

c. Pada atribut RA, menetapkan peran dan tanggungjawab organisasi IT baik staf maupun dengan pihak ketiga. Menentukan definisi dari fungsi-fungsi yang dilakukan personil IT dan yang dilakukan oleh pengguna.

d. Pada atribut GSM, mendefinisikan kerangka kerja proses IT untuk melaksanakan rencana strategis IT dan menetapkan lingkungan internal kontrol. Membangun bagian komite strategi IT yang dapat membantu ketua dalam mengambil keputusan.
Tindakan yang perlu dilakukan agar nilai kematangan pada tingkat kematangan 2 mencapai tingkat kematangan 3 pada proses IT AI7, yaitu:

a. Pada atribut AC, melakukan komunikasi dan meninjau kebutuhan perubahan yang diperlukan. Membuat dokumentasi dari hasil pengujian sistem terhadap lingkungan untuk dilakukan promosi produksi.

b. Pada atribut PSP, memastikan seluruh entitas yang ada memahami kebijakan, standar dan prosedur yang dijalankan. Menetapkan prosedur yang sesuai dengan standar untuk menanggapi perubahan yang terjadi pasca pelaksanaan.

c. Pada atribut TA, menggunakan perangkat yang sesuai dengan standar penyebaran informasi dan dapat mengikuti perubahan. Membuat perencanaan dan perbaikan yang terjadwal.

d. Pada atribut SE, melakukan pelatihan untuk staf dan menerapkan job enrichment.

e. Pada atribut RA, menetapkan peran dan tanggungjawab organisasi IT sesuai dengan keahlian yang dimiliki untuk menanggapi perubahan. Identifikasi pemilik proses serta definisikan tanggung jawab dan akuntabilitas.

f. Pada atribut GSM, melakukan pengawasan, memberi tanggapan terhadap perubahan dan melakukan tes penerimaan akhir.

\subsubsection{Pencapaian Maturity Level 4}

Tindakan yang perlu dilakukan agar nilai kematangan pada tingkat kematangan 3 mencapai tingkat kematangan 4 pada proses IT PO4, yaitu:

a. Pada atribut AC, menetapkan organisasi IT yang dapat merespon perubahan secara proaktif termasuk semua peran penting untuk memenuhi kebutuhan.

b. Pada atribut PSP, menetapkan internal good practice dalam organisasi dan fungsi-fungsi IT serta mendokumentasikan prosedur-prosedur yang ada dalam pengelolaan proses dan organisasi IT serta hubungan dengan pihakpihak terkait.

c. Pada atribut TA, menggunakan perangkat terkini yang telah terintegrasi lalu lakukan pemeliharaan perangkat dan perbaharui secara berkala.

d. Pada atribut SE, keahlian yang dimiliki kepala IT dalam mengatur organisasi IT dan melakukan uji kompetensi atau uji kemampuan sebagai cara untuk mengevaluasi keahlian yang dimiliki staf.

e. Pada atribut RA, menetapkan manajemen IT, kepemilikan proses, akuntabilitas dan 
tanggungjawab. Mengontrol jalannya tugas dan tanggungjawab masing-masing staf IT sesuai dengan fungsi yang telah ditetapkan.

f. Pada atribut GSM, analisa kerangka kerja proses IT yang diterapkan dan sesuaikan dengan rencana strategis IT. Menggunakan metrik yang dapat mengukur proses dan fungsi IT dalam mendukung tujuan STIE 45 Mataram dan mengkritisi faktor kesuksesan yang berfokus pada pelayanan dan hubungan kerjasama.

Tindakan yang perlu dilakukan agar nilai kematangan pada tingkat kematangan 3 mencapai tingkat kematangan 4 pada proses IT AI7, yaitu:

a. Pada atribut AC, melakukan evaluasi dan tinjauan pasca pelaksanaan terhadap laporan dan kebutuhan teknologi. Tanggapi promosi yang dilakukan dengan meninjau rencana implementasi. Lanjutkan dengan memperoleh persetujuan dari pemilik sistem.

b. Pada atribut PSP, kebijakan, standar dan prosedur dievaluasi dan di akreditasi untuk dapat diterima bersama sehingga jelas dalam menanggapi perubahan yang terjadi. Dokumentasikan semua proses dari kebijakan yang telah disetujui dan ditandatangani oleh Ketua STIE 45 Mataram.

c. Pada atribut TA, penggunaan perangkat dikelola dengan baik dan dilakukan perawatan berkelanjutan. Dokumentasi penggunaan perangkat untuk mengetahui perubahan kebutuhan dan perangkat yang perlu mendapat pembaharuan.

d. Pada atribut $\mathrm{SE}$, meningkatkan pelatihan yang diberikan, baik kepada staf maupun pengguna dengan didampingi staf ahli untuk menjadi panduan. Pelatihan dilakukan secara berkala dan tidak menunggu perubahan yang terjadi.

e. Pada atribut RA, menentukan dan menerapkan pembagian peran dan tanggungjawab sesuai dengan hasil dari rencana uji dan implementasi. Mengontrol tanggung jawab yang diberikan dengan memantau praktik kerja dan tanggapan terhadap perubahan yang terjadi

f. Pada atribut GSM, tingkatkan pengawasan terhadap pengujian perubahan kebutuhan yang terjadi dengan mempertimbangkan keamanan dan kinerja. Melakukan evaluasi terhadap hasil dari proses pengujian sebagaimana yang telah ditentukan oleh rencana uji serta melakukan perbaikan.

\subsubsection{Pencapaian Maturity Level 5}

Tindakan yang perlu dilakukan agar nilai kematangan atribut SE mencapai tingkat kematangan 5 pada proses IT PO4, yaitu:

Pada atribut SE, melakukan evaluasi terhadap keahlian yang dimiliki organisasi IT secara berperiodik. Membudayakan sistem knowledge sharing dengan menyediakan perangkat knowledge management system. Mempertimbangkan untuk mendatangkan ahli dari luar sebagai konsultan yang mampu memberikan panduan untuk hal-hal yang memang dirasa perlu melibatkan pihak luar.

\subsection{Rencana Aksi}

Berikut adalah penjabaran lebih lanjut rencanarencana aksi yang harus dilakukan:

a. Menanggapi persyaratan tata kelola yang sesuai arahan atasan, ditempuh dengan:

1. Menentukan kebijakan dan prosedur mengenai kontrak pegawai dengan memperkenalkan stakeholder serta menjelaskan peran, tanggung jawab dan wewenang yang dimilikinya.

2. Menetapkan badan dan struktur organisasi IT yang jelas sebagai sarana berkumpul untuk bertukar pendapat mengenai kegiatan inti proses IT yang diberikan atasan. Fungsi pengawasan dalam menjalankan proses IT juga lebih terkontrol dengan adanya staf ahli yang mengepalai bagian IT.

b. Menanggapi kebutuhan STIE 45 Mataram agar sejalan dengan strategi yang dibuat, dapat dicapai dengan:

1. Mendefinisikan kerangka kerja proses IT yang didalamnya mencakup struktur proses IT, kepemilikan, jadwal pelaksanaan, parameter keberhasilan, solusi perbaikan, kebijakan dan rencana untuk mencapainya yaitu dengan menjabarkan proses IT yang akan dijalankan.

2. Menganalisa kerangka kerja proses IT yaitu dengan melihat kepuasan stakeholder dan membuat dokumentasi kesesuaian proses IT yang dijalankan dengan strategi yang dibuat.

c. Membuat ketangkasan di bidang IT, ditempuh melalui:

1. Melakukan pelatihan formal terhadap seluruh staf IT secara periodik agar keahlian IT yang dimiliki merata untuk setiap staf. Agar pelatihan tetap teratur dan dapat meningkatkan keahlian yang dimiliki secara bertahap. 
2. Melakukan uji kompetensi sebagai sarana untuk mengetahui perkembangan keahlian yang dimiliki staf IT. Selain itu dengan melakukan sertifikasi sesuai dengan peran dan tanggung jawab masing-masing juga dapat dilakukan.

d. Memastikan bahwa penyebaran informasi dan pertukaran informasi dapat dipercaya, ditempuh melalui:

1. Melakukan tes pengujian yang cukup yaitu dengan memastikan sistem yang digunakan sesuai dengan fungsi dan manfaatnya untuk meminimalisir terjadinya kesalahan saat sistem diterapkan ke lingkungan.

2. Melakukan evaluasi terhadap hasil proses pengujian yaitu dengan memastikan perubahan yang dilakukan sudah sesuai keinginan sebelum dipromosikan ke pihak atas.

e. Mengurangi cacat solusi dan proses yang dikerjakan secara berulang-ulang, ditempuh melalui:

1. Melakukan pengawasan dan menanggapi perubahan dengan cara mengadakan rapat strategi secara rutin untuk dapat bertukar informasi dan membahas permasalahan ataupun adanya perubahan dalam proses yang digunakan.

2. Melakukan evaluasi terhadap hasil proses pengujian. Hal ini dilakukan untuk melihat kemungkinan kesalahan yang terjadi dan dapat segera mencari solusi perbaikan.

3. Melakukan perbaikan terhadap kesalahan yang teridentifikasi dilakukan agar saat perangkat diterapkan di lingkungan sudah tepat dan sesuai dengan tujuan STIE 45 Mataram.

f. Menanggapai perubahan kebutuhan STIE 45 Mataram sejalan dengan strategi yang telah dibuat, ditempuh melalui:

1. Melakukan tes pengujian yang cukup yaitu dengan memastikan sistem yang digunakan sesuai dengan fungsi dan manfaatnya.

2. Membuat dokumentasi dari hasil pengujian yang berguna sebagai salah satu acuan bahwa perangkat yang digunakan sudah cocok dengan tujuan STIE 45 Mataram.

g. Memastikan aplikasi terintegrasi ke dalam proses bisnis, ditempuh melalui:

1. Melakukan evaluasi dan tinjauan pasca pelaksanaan dapat dilakukan pada saat rapat rutin organisasi IT.
2. Tanggapi dan setujui promosi yang dilakukan yaitu dengan keterlibatan stakeholder dalam meninjau solusi teknologi yang diberikan untuk disetujui. Keterlibatan stakeholder juga sebagai salah satu cara untuk memastikan apakah sistem yang diajukan sudah sesuai dengan standar.

h. Memastikan penggunaan dan fungsi yang tepat dari aplikasi dan solusi teknologi, ditempuh melalui:

1. Membuat dokumentasi dari hasil pengujian yang berguna sebagai salah satu acuan bahwa perangkat yang digunakan sudah cocok dengan tujuan. Kesalahan yang terjadi selama proses pengujian akan di dokumentasi dan dapat dijadikan salah satu solusi.

2. Melakukan tes penerimaan akhir, yaitu dengan keterlibatan stakeholder dalam menguji coba sistem yang mendapat perubahan atau sistem baru. Keterlibatan stakeholder juga sebagai salah satu cara untuk memastikan bahwa sistem yang akan digunakan siap untuk diterapkan.

3. Melakukan perbaikan terhadap kesalahan yang teridentifikasi yaitu sebelum disetujuinya sistem yang diajukan untuk meningkatkan kepercayaan stakeholder terhadap sistem baru yang akan diterapkan.

i. Memastikan layanan IT dan infrastruktur IT benar-benar dapat bertahan dan diperbaharui dari kegagalan karena kesalahan, serangan atau bencana, ditempuh melalui:

1. Menggunakan komponen yang standar yaitu komponen yang tidak tergantung pada vendor tertentu. Sehingga penggantian pada suatu komponen yang mengalami kesalahan ataupun terjadi gangguan karena bencana dapat dilakukan dengan mudah dan cepat.

2. Dokumentasikan penggunaan perangkat yang memerlukan pembaharuan agar dalam rencana kedepannya terdapat gambaran dalam melakukan perubahan atau pembaharuan teknologi yang diperlukan, baik untuk sistem lama maupun sistem yang baru.

\section{KESIMPULAN DAN SARAN}

\subsection{Kesimpulan}

Dari hasil penelitian di atas, dapat ditarik beberapa kesimpulan sebagai berikut: 
a. Langkah-langkah untuk mendapatkan rekomendasi telah disusun dengan mengacu kepada visi, misi dan tujuan STIE 45 Mataram yaitu dengan melakukan studi pustaka, mengidentifikasi masalah, mengidentifikasi Balanced Scorecard, mengidentifikasi Business Goals, IT Goals dan IT Process, melakukan wawancara dan kuesioner lalu menghitung hasil kuesioner dengan melakukan uji realibilitas dan validitas serta menghitung maturity level.

b. Dalam proses tata kelola teknologi informasi di STIE 45 Mataram sudah memiliki kesadaran dalam penerapan teknologinya. Hal ini berarti sebagian besar prosesnya sudah diatur tetapi tidak konsisten karena masih terdapat ketergantungan terhadap pengetahuan individu, sehingga kemungkinan terjadinya kesalahan cukup besar.

c. Atribut pada proses PO4 dan Al7 kondisi yang diharapkan berada pada tingkat kematangan 4, berarti bahwa tingkat pengawasan dan mengukur kepatuhan sudah dilakukan terhadap prosedur yang ada, dapat mengambil tindakan atas ketidakefektifan proses yang terjadi. Terdapat proses peningkatan secara konstan dan otomasi perangkat untuk memantau berbagai sumber daya Teknologi Informasi.

d. Untuk atribut SE pada proses PO4 diharapkan berada pada tingkat kematangan 5 , yaitu proses diperbaiki pada tingkat praktek terbaik dengan keahlian yang dimiliki staf pada bagian IT secara teknis dapat diandalkan dan memiliki struktur organisasi yang berjalan dengan baik. Staf juga memiliki kontrak kerja yang jelas dan dipatuhi, sehingga menghilangkan ketergantungan terhadap individu tertentu saja.

e. Rekomendasi yang diberikan berupa langkahlangkah dalam meningkatkan maturity level secara bertahap untuk setiap atributnya, lalu diberikan rencana aksi yang di dalamnya termuat kegiatan-kegiatan yang dilengkapi dengan jadwal pelaksanaan dan estimasi waktu yang dapat dijalankan.

\subsection{Saran}

a. Dalam melakukan perbaikan sebaiknya dijalankan secara bertahap sesuai dengan kebutuhan dan memastikan suatu perbaikan telah selesai secara maksimal agar kedepannya tidak terjadi banyak perbaikan yang sama dilakukan secara berulang-ulang.

b. Untuk dapat menerapkan tata kelola seperti yang telah dijabarkan di atas perlu adanya perumusan cara dan target waktu yang dilakukan oleh STIE 45 Mataram dengan mempertimbangkan sumber daya dan biaya yang dimiliki.

c. Agar hasil tata kelola dapat lebih maksimal, diharapkan pihak STIE 45 Mataram dapat memadukan hasil penelitian serupa pada proses IT yang lain, sehingga pelaksanaannya dapat lebih terintegrasi dan mendapatkan hasil yang maksimal.

\section{DAFTAR PUSTAKA}

[1] A. Suryani, "Pengembangan Model Information Technology (IT) Governance Pada Organisasi Pendidikan Tinggi Menggunakan COBIT 4.1 Domain PO Dan Al," Seminar Nasional Informatika, 2009.

[2] A. S. Pardiansyah, "Audit Tata Kelola Teknologi Informasi Program Studi Sistem Informasi Sekolah Tinggi Manajemen Informatika Dan Komputer (STMIK) Lombok Menggunakan Framework Cobit," Indonesian Journal on Software Engineering, vol. 1, no. 1, pp. 17-25, 2015.

[3] R. O. Saputro, "Tata Kelola Teknologi Informasi Berdasarkan Framework COBIT 4.1 Pada Perusahaan Daerah Air Minum Surabaya," Fakultas Teknologi dan Informatika STIKOM Surabaya, pp. 220-222, 2017.

[4] M. Hamka and W. Feri, "Analisis Pengukuran Tingkat Kematangan Aplikasi E-Commerce Menggunakan COBIT 4.1 (Studi Kasus: Kelompok UMKM Etsa Luhur)," Teknik Informatika Universitas Muhammadiyah Purwokerto, vol. III, no. 4, pp. 181186, 2015.

[5] I. I. Governance, "COBIT ver. 4.1: Framework, Control Objectives, Management Guidelines, Maturity Model," Rolling Meadow, 2007.

[6] D. Yuniasari and E. D. Retnani, "Penilaian Kinerja Perusahaan Dengan Pendekatan Balanced Scorecard pada PT Prudental Life Assurance," Sekolah Tinggi IImu Ekonomi Indonesia Surabaya, Surabaya, vol. 5, no. 10, 2016.

[7] A. P. Utomo and N. Mariana, "Analisis Tata Kelola Teknologi Informasi ( It Governance) pada Bidang Akademik dengan Cobit Frame Work, Studi Kasus pada Universitas Stikubank Semarang," Dinamik, vol. 16, no. 2, pp. -, 2011.

[8] H. Hasanah, "Teknik-Teknik Observasi," Fakultas Dakwah dan Komunikasi Universitas Islam Negeri Semarang, vol. 8, no. 1, pp. 21-46, 2016 